\title{
HUBUNGAN KONSEP DIRI DENGAN PERILAKU HYGIENE ORGAN REPRODUKSI REMAJA PUTRI SMAN-10 BANJARMASIN
}

Nita Hestiyana ${ }^{1}$, Dini Rahmayani ${ }^{2}$, A’bdah Rasyidah Imbran $^{*}$

${ }^{1}$ Akademi Kebidanan Sari Mulia Banjarmasin

${ }^{2}$ Sekolah Tinggi Ilmu Kesehatan Sari Mulia Banjarmasin

*Korespondensi Penulis. Telpon 085252759792, nitahestiyana@gmail.com

\begin{abstract}
ABSTRAK.
Latar Belakang: Organ reproduksi merupakan salah satu bagian yang sensitif, sehingga memerlukan perawatan khusus untuk menjaganya. Kurangnya kesadaran dalam menjaga kebersihan organ reproduksi disebabkan oleh beberapa faktor salah satunya konsep diri. Semenjak konsep diri terbentuk, seseorang akan berperilaku sesuai dengan konsep dirinya dan jika perilaku seseorang tidak konsisten dengan konsep dirinya, maka akan muncul perasaan tidak nyaman dalam dirinya.

Tujuan: Mengetahui Hubungan antara Konsep Diri dengan Perilaku Hygiene Organ Reproduksi pada Remaja Putri SMAN 10 Banjarmasin.

Metode: Penelitian ini bersifat kuantitatif dengan desain penelitian observasional analitik dengan pendekatan Cross Sectional .Subjek dalam penelitian ini adalah seluruh siswi perempuan kelas X SMAN-10 Banjarmasin. Populasi dalam penelitian ini adalah 109 orang dengan jumlah sampel 86 orang dengan menggunakan teknik Simple Random Sampling dan menggunakan uji chi square.

Hasil: Hasil uji statistik Chi-Square didapatkan nilai $\mathrm{p}$ value 0,000 dimana $\propto=0,05$. Jika $\mathrm{P}$ value $<\propto$ maka dapat dismpulkan bahwa Ho ditolak dan Ha diterima artinya ada hubungan antara konsep diri dengan Perilaku Hygiene Organ Reproduksi Remaja Putri Kelas X SMAN-10 dengan nilai OR 6,7 .

Simpulan:Konsep diri yang positif akan dapat menyadari kekurangan yang dimiliki dan kemudian akan memperbaikinya. Sehingga semakin tinggi kesadaran akan konsep diri positif yang dimiliki seorang remaja makan akan semakin baik dalam menjaga perilaku hygiene organ reproduksi. Perilaku hygiene organ reproduksi yang baik akan melindungi remaja dari penyakit organ reproduksi yang tidak diinginkan.
\end{abstract}

Kata kunci : Konsep Diri, Perilaku Hygiene Organ Reproduksi 


\begin{abstract}
Background: The reproductive organs are one of the sensitive parts, so it requires special care to keep them. Lack of awareness in maintaining the cleanliness of reproductive organs caused by several factors one of them self concept. Since the concept of self is formed, a person will behave according to his self concept and if a person's behavior is inconsistent with her self concept, then it will arise feelings uncomfortable within him.

Objective: To Know The Relationship between Self Concept and Hygiene Behavior of Reproductive Organs in Young Women SMAN 10 Banjarmasin.

Method: This research is quantitative with analytic observational research design with Cross Sectional approach. The subject in this research is all female students of class X SMAN-10 Banjarmasin. The population in this study was 109 people with a sample of 86 people using Simple Random Sampling technique and using chi square test.

Result: Chi-Square statistical test results obtained $\mathrm{p}$ value 0,000 where $\alpha=0.05$. If $\mathrm{P}$ value $<\alpha$ then it can be conclusion that Ho rejected and $\mathrm{Ha}$ accepted means there is a relationship between selfconcept with Hygiene Behavior of Young Women Reproductive Organ of Class X SMAN-10 with the value of OR 6.7.

Conclusion: A positive self-concept will be able to recognize the shortcomings and then improve them. So the higher the awareness of positive self-concept that a teenager eats will be better in maintaining hygiene behavior of reproductive organs. Good hygiene behavior of reproductive organs will protect teenagers from unwanted reproductive organ disease.
\end{abstract}

Keywords: Self Concept, Reproductive Hygiene Organs Behavior 


\section{PENDAHULUAN}

Remaja adalah masa transisi antara masa kanak-kanak dan dewasa, dimana terjadi pacu tumbuh, timbul ciri-ciri seksual sekunder, tercapainya fertilitas, dan terjadi perubahan psikologis kognitif untuk tercapainya tumbuh kembang yang optimal tergantung pada potensi biologiknya. Menurut World Health Organization (WHO) 2014, remaja adalah penduduk dalam rentan usia 10-19 tahun, menurut Peraturan Menteri Kesehatan RI Nomor 25 tahun 2014, remaja adalah penduduk dalam rentan usia 10-18 tahun dan menurut Badan Kependudukan dan Keluarga Berencana (BKKBN) rentang usia remaja 1024 tahun dan belum menikah (Kepmenkes RI, 2015). Menurut World Health Organization (2014) jumlah kelompok usia 10-19 tahun di Indonesia menurut Sensus penduduk 2010 sebanyak 43,5 juta atau sekitar $18 \%$ dari jumlah penduduk (Kepmenkes RI, 2015).

Kesehatan reproduksi menurut WHO adalah suatu keadaan fisik, mental dan sosial yang utuh, bukan hanya bebas dari penyakit atau kecatatan dalam segala aspek yang berhubungan dengan sistem reproduksi (Lestari, 2013).

Konsep diri adalah pandangan pribadi yang dimiliki seseorang tentang diri sendiri atau persepsi terhadap aspek diri yang meliputi aspek fisik, sosial dan aspek psikologis yang didasarkan pada pengalaman dan interaksi terhadap orang lain (Sobur, 2009).

Perubahan fisik yang tampak jelas pada remaja yaitu tubuh berkembang pesat sehingga mencapai bentuk orang dewasa yang disertai pula dengan berkembangnya kapasitas reproduksi, sehingga remaja perlu memahami pentingnya kesehatan reproduksi. Kesehatan reproduksi remaja adalah suatu kondisi sehat yang menyangkut sistem, fungsi dan proses reproduksi yang dimiliki remaja (Wiknjosastro, 2007).

Salah satu organ tubuh yang sensitif dan memerlukan perawatan khusus adalah organ reproduksi. Pengetahuan dan perawatan yang baik merupakan faktor penentu dalam memelihara kesehatan reproduksi. Menjaga kesehatan berawal dari menjaga kebersihan. Keringat dapat membuat tubuh menjadi 
lembab terutama pada organ seksual dan reproduksi yang tertutup dan berlipat, sehingga dapat membantu pertumbuhan bakteri dan jamur termasuk vagina (Kissanti, 2008). Kurangnya kebersihan organ reproduksi merupakan salah satu penyebab infeksi alat reproduksi seperti Keputihan, Kanndidiasis Vulbovaginitis Vaginosis bacterial, dan Trikomoniasis (Pinem, 2012) dan Infeksi alat reproduksi luar bisa masuk sampai ke alat reproduksi dalam dan menyebabkan kanker rahim (Kissanti, 2008).

Konsep diri merupakan suatu mekanisme yang dapat mengatur dan mengarahkan perilaku remaja. Salah satunya mekanisme yang perlu dimiliki adalah konsep diri. Konsep diri terbagi menjadi 2 yaitu konsep diri postif dan konsep diri negatif. Konsep diri positif adalah individu yang mempunyai keyakinan yang kuat dalam menghadapi kesulitan dan mengambil keputusan yang terbaik dalam hidupnya dan mampu bertindak berdasarkan penilaian yang baik tanpa rasa bersalah yang berlebihan atau menyesali tindakan orang lain tidak menyukai tindakan nya. Konsep diri positif selalu menjaga perilaku hygine organ reproduksi sehingga remaja memiliki sistem kontrol dalam dirinya. Konsep diri negatif merupakan evaluasi negatif membenci diri, perasaan rendah diri, serta kurang menghargai dan menerima diri serta kurangnya rasa percaya diri yang menyebabkan seseorang kurang mengontrol perilakunya terhadap perilaku hygiene organ reproduksinya (Miraningsih, 2013).

SMAN-10 Banjarmasin merupakan sebuah sekolah pendidikan yang terletak di lokasi yang dekat dengan daerah pemukiman yang padat penduduk. Berdasarkan survey yang dilakukan oleh peneliti didapatkan bahwa SMAN-10 Banjarmasin berada di wilayah kerja Puskesmas Pekauman untuk masalah yang menyangkut tentang remaja. Melalui program PKPR dan Genre, remaja mendapatkan penyuluhan tentang kesehatan reproduksi melalui kegiatan UKS (Usaha Kesehatan Sekolah) dan ekstrakulikuler PMR (Palang merah Remaja) yang terdapat di SMAN-10 Banjarmasin. Berdasarkan data yang di dapatkan dari Puskesmas Pekauman masalah terbanyak yang terjadi pada remaja menyangkut kesehatan organ reproduksi 
adalah Trikomoniasis $63 \%$ pada tahun 2016

(Puskesmas Pekauman, 2016). Hal tersebut berkaitan dengan wilayah pemukiman yang dikelilingi oleh sungai-sungai dan kehidupan mereka sehari-hari menggunakan air dari sungai tetapi ada sebagian menggunakan PDAM.

Berdasarkan studi pedahuluan yang dilakukan dengan cara wawancara dengan 10 siswi perempuan kelas $\mathrm{X}$ di dapatkan hasil bahwa 6 remaja putri tidak tahu cara menjaga dan merawat kesehatan organ reproduksi yang benar. Mereka memiliki sedikit pengetahuan tentang hal tersebut dan kurangnya media informasi tentang kesehatan reproduksi. 4 orang mengetahuinya secara baik karena mereka aktif mengikuti kegiatan penyuluhan. Berdasarkan hal tersebut maka peneliti akan melakukan penelitian Hubungan Konsep Diri Dengan Perilaku Hygiene Organ Reproduksi Pada Remaja di SMAN-X Banjarmasin.

\section{BAHAN DAN METODE}

Penelitian ini dilaksanakan di SMAN-10 Banjarmasin. Populasi dalam penelitian ini adalah adalah seluruh siswa perempuan kelas X SMAN 10 Banjarmasin jumlahnya 109 orang. Jumlah sampel dalam penelitian ini adalah 86 enam orang. Jumlah sampel ini didapatkan dengan menggunakan rumus solvin.

Teknik sampling yang digunakan adalah simple random sampling dengan metode pengundian.

\section{HASIL PENELITIAN}

1. Analisis Univariat

a. Konsep diri

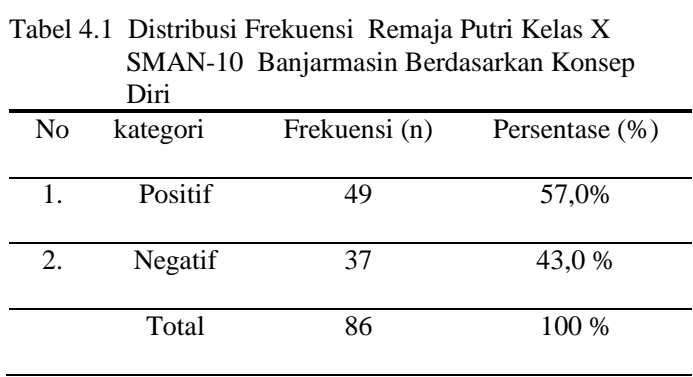

Berdasarkan tabel 4.1 di dapatkan hasil bahwa konsep diri paling banyak dimiliki remaja putri kelas X SMAN-10 Banjarmasin adalah konsep diri positif yaitu 49 orang $(57,0 \%)$.

b. Perilaku Hygiene Organ Reproduksi

\begin{tabular}{cccc} 
Tabel 4.2 & $\begin{array}{l}\text { Distribusi Frekuensi remaja putri kelas X } \\
\text { SMAN- } \\
\text { Hygiene }\end{array}$ & Organjarmasin Rerpduksi & berdasarkan Perilaku \\
\hline No & Kategori & Frekuensi (n) & Persentase (\%) \\
\hline $\mathbf{1 .}$ & Baik & 45 & $52,3 \%$ \\
\hline $\mathbf{2 .}$ & Tidak Baik & 41 & $47,7 \%$ \\
\hline & Total & 86 & $100 \%$
\end{tabular}


Berdasarkan Tabel 4.2 di dapatkan hasil

bahwa perilaku hygiene organ reproduksi paling banyak pada remaja

putri kelas X SMAN-10 Banjarmasin berperilaku baik yaitu 45 orang $(52,3 \%)$

2. Analisis Bivariat

Hubungan Konsep diri dengan perilaku Hygiene Organ Reproduksi remaja putri SMAN-10 Banjarmasin

\begin{tabular}{|c|c|c|c|c|c|c|}
\hline \multirow[t]{3}{*}{ no } & \multirow{3}{*}{$\begin{array}{c}\text { Konsep } \\
\text { diri }\end{array}$} & \multicolumn{4}{|c|}{ Perilaku hygiene organ reproduksi } & \multirow{3}{*}{$\begin{array}{c}\text { total } \\
\mathrm{N}\end{array}$} \\
\hline & & \multicolumn{2}{|c|}{ baik } & \multicolumn{2}{|c|}{ Tidak baik } & \\
\hline & & $\mathrm{N}$ & $\%$ & $\mathrm{~N}$ & $\%$ & \\
\hline 1 & Positif & 35 & $71,4 \%$ & 14 & $28,6 \%$ & 49 \\
\hline 2 & Negatif & 10 & $25,7 \%$ & 27 & $73,0 \%$ & 37 \\
\hline & total & 45 & $52,3 \%$ & 41 & $47,7 \%$ & 86 \\
\hline \multicolumn{7}{|c|}{ Uji Statistik Chi Square, P Value 0,000, OR: 6,7 } \\
\hline & & & & & & \\
\hline
\end{tabular}

menunjukkan bahwa dari 86 responden yang dilakukan penelitian di dapatkan hasil remaja Putri kelas X SMAN-10 Banjarmasin yang memiliki konsep diri positif dengan perilaku hygiene organ reproduksi yang baik yaitu 35 orang $(71,4 \%)$ dan yang konsep diri negatif yang memiliki perilaku hygiene organ reproduksi baik yaitu 10 orang $(25,7 \%)$.
Hasil uji statistik Chi-Square didapatkan $\mathrm{p}=0,000 \propto \alpha=0,05$ maka $\mathrm{p}<$ $\propto$ maka dapat dismpulkan bahwa Ho ditolak dan $\mathrm{Ha}$ diterima artinya ada hubungan antara konsep diri dengan perilaku hygiene organ reproduksi remaja putri kelas X SMAN-10 Banjarmasin dengan nilai Odd Ratio 6,7 yang artinya remaja putri dengan konsep diri negatif berisiko 6,7 kali lebih besar memiliki perilaku hygne organ reproduksi yang tidak baik dibandingkan dengan remaja putri yang memiliki konsep diri positif.

\section{PEMBAHASAN}

1. Analisa Univariat

a. Konsep diri

Berdasarkan hasil penelitian yang dilakukan kepada 86 responden diketahui bahwa mayoritas remaja putri di SMAN-10 Banjarmasin memiliki konsep diri positif yaitu 49 orang $(57,0 \%)$ yang di dadapatkan dari hasil jawaban kuesioner.

Konsep diri adalah semua ide, pikiran, perasaan, kepercayaan serta 
pendirian yang diketahui individu tentang dirinya dan mempengaruhi individu dalam berhubungan dengan orang lain (Yusuf, 2015) yang terdiri dari 5 komponen yaitu Gambaran diri,ideal diri, harga diri, peran serta identitas diri. Konsep diri yang terbentuk pada masa remaja dapat mempengaruhi pola pikir mereka sehingga diperlukan Konsep diri.

Konsep diri terbagi menjadi 2 yaitu konsep diri positif dan konep diri negatif. Sebaiknya seorang remaja memiliki konsep diri yang positif yaitu individu yang mempunyai keyakinan yang kuat dalam menghadapi kesulitan dan mengambil keputusan yang terbaik dalam hidupnya dan mampu bertindak berdasarkan penilaian yang baik tanpa rasa bersalah yang berlebihan sedangkan jika seorang remaja memiliki konsep diri negatif akan memiliki pandangan negatif tentang dirinya maupun orang lain. Hal ini tentunya akan mempengaruhi hubungan individu tersebut dengan lingkungan sekitarnya.
Dirinya

juga

mempunyai

kecenderungan mendapat respon yang negatif dari orang lain dan lingkungannya. Selain itu, individu dengan konsep diri negatif selalu pesimis dalam menatap dan menjalani masa depannya

b. Perilaku hygiene organ reproduksi

Berdasarkan penelitian yang dilakukan di SMAN-10 Banjarmasin sebagian besar memiliki perilaku Hygiene Organ Reproduksi yang baik berjumlah 45 orang $(52,3 \%)$. Hal ini diasumsikan bahwa kesadaran mereka tentang menjaga perilaku hygiene organ reproduksi cukup baik. Seorang remaja yang memiliki perilaku hygiene organ reproduksi yang baik akan membatu remaja dalam bergaul dan beradaptasi dengan lingkungan sekitar dan juga selalu dapat menjaga kebersihan organ reproduksi dengan baik dan paham bagaimana cara menjaganya sedangkan remaja yang memiliki perilaku hygiene organ reproduksi yang tidak baik dapat membawa remaja menjadi seseorang 
yang tidak bisa cara mejaga kebersihan organ reproduksi yang benar, sehingga dapat menyebabkan infeksi atau penyakit pada organ reproduksi.

Perilaku hygiene organ reproduksi adalah usaha untuk mempertahankan atau memperbaiki kesehatan dengan memelihara kebersihan alat reproduksi. Menjaga kesehatan berawal dari menjaga kebersihan. Hal ini juga berlaku bagi kesehatan organ-organ seksual, termasuk vagina (Kissanti, 2008). Faktor-faktor yang mempengaruhi perilaku hygiene organ reproduksi, antara lain faktor internal (tingkat kecerdasan, tingkat emosional, konsep diri, jenis kelamin) dan faktor eksternal (lingkungan, ekonomi dan politik). Faktor-faktor tersebut saling berinteraksi secara langsung dan tidak langsung dalam membentuk perilaku hygiene organ reproduksi.

\section{Analisa Bivariat}

Hubungan Konsep diri dengan perilaku hygiene organ reproduksi pada remaja putri
Konsep diri menimbulkan perilaku yang membuat orang lain dapat menerima remaja tersebut. Perilaku yang paling umum yaitu perilaku seksual yang mendorong remaja untuk selalu menjaga kebersihan organ reproduksi (Hurlock, 2008). Perilaku hygiene organ reproduksi yang ditampilkan remaja akan mengalami perubahan menyesuaikan dengan perubahan fisik yang terjadi pada dirinya. Menurut Stuart dan Sudeen yang dikutip oleh Salbiah (2008) konsep diri yang positif akan memiliki keseimbangan dalam kehidupan termasuk dalam perilaku menjaga kesehatan reproduksi. Konsep diri yang positif akan membawa keyakinan pada remaja yang kuat dalam menghadapi kesulitan dalam mengambil keputusan yang terbaik dalam hidupnya dan mampu bertindak berdasrkan penilaian yang baik tanpa rasa bersalah yang berlebihan atau menyesali tindakan orang lain yang tidak menyukainya.

Dari hasil penelitian didapatkan bahwa terdapat hubungan antara konsep diri dengan perilaku hygiene organ reproduksi 
remaja putri. Seorang remaja yang memiliki konsep diri positif akan selalu menjaga perilaku hygiene organ reproduksinya sedangkan remaja putri yang memiliki konsep diri negatif cenderung memiliki perilaku hygiene organ reproduksi yang tidak baik. Tetapi masih banyak faktor lain yang mempengaruhi konsep diri seseorang. Hal itu biasanya dipengaruhi oleh lingkungan sekitar yang mendorong remaja tersebut untuk mengajari bagaimana cara menjaga kebersihan organ reproduksi. Selain itu sebagian kecil seorang remaja yang memiliki konsep diri poistif tetapi memiliki perilaku hygiene organ reproduksi yang tidak baik, karena seorang remaja sebetulnya mengenal dirinya baik sekali tetapi mungkin karena pola didik yang keras sehingga menciptakan citra diri yang tidak mengizinkan melakukan hal-hal yang tidak diketahuinya sehingga mempengaruhi pola pikir remaja tersebut.

Perilaku Hygiene organ reproduksi banyak dipengaruhi oleh pandangan dan karakteristik individu. Apabila individu memandang dirinya sebagai orang yang mampu menjaga kesehatan reproduksinya maka individu itu akan menunjukkan perilaku hygiene organ reproduksi agar terhindar dari infeksi dan penyakit yang ada dalam organ tersebut. Pengetahuan kesehatan reproduksi remaja penting diberikan kepada remaja sehingga remaja dapat menggunakan waktu remajanya yang terbebas untuk melakukan kegiatan produktif dan sehat, karena remaja dengan pengetahuan reproduksi yang rendah cenderung melakukan berbagai tindakan yang membahayakan kesehatan. Sedangkan remaja yang memiliki konsep diri yang negatif akan membawa remaja tersebut menjadi seseorang yang tidak memperhatikan kebersihan organ reproduksi, sehingga menurunkan kualitas kepercayaan dirinya sebagai remaja.

\section{UCAPAN TERIMA KASIH}

Peneliti mengucapkan terimakasih kepada Civitas Akademika Sari Mulia dan orang tua serta rekan-rekan yang memberikan motivasi. 


\section{DAFTAR PUSTAKA}

Agustiani, Hendriati. 2009. Psikologi Perkembangan: Pendekatan Ekologi Kaitannya dengan Konsep Diri dan Penyesuaian Diri pada Remaja. Bandung: PT Refika Aditama.

Arini A. 2006. Konsep Diri Positif, Menentukan Presentasi Anak. Yogyakarta: Kanisius.

Azwar S. 2009. Penyusunan Skala Psikologi. Yogyakarta: Pustaka Pelajar.

Andira D. 2010. Seluk Beluk Kesehatan Reproduksi Wanita. Jogyakarta: A plus Books.

Chotimah, Chusnul, 2015: Hubungan Religiusitas, Konsep Diri Dan Keintiman

Keluarga, Dengan Perilaku Seksual Pranikah Pada Mahasiswa Program Studi D3 Kebidanan Poltekkes Bahkti Mulia Sukoharjo.[Thesis]. Surakarta: Universitas Sebelas Maret.

Hendriati A. 2006. Psikologi Perkembangan, Pendekatan Ekologi, Kaitannya Dengan Konsep Diri Dan Penyesuaian Diri Pada Remaja. Bandung: PT Refika Aditama.

Hurlock Elizabeth B. 2010. Perkembangan Anak. Volume ke 6. Jilid ke 2. Penerjemah. Jakarta : Erlangga.

Hidayat, Alimul Aziz. 2008. Metode Penelitian Keperawatan Dan Teknik Analisis Data. Jakarta: Salemba Medica.

Imbron A. 2014. Pendidikan Kesehatan Reproduksi Remaja, PEER Edukator Dan Efektivitas Program PIK-KRR Di Sekolah. Joyjakarta: A Media.

Jalaluddin R. 2007. Psikologi komunikasi. Bandung: PT Remaja Rosdakarya.

Kepmenkes, RI. 2015. Situasi Kesehatan Reproduksi Remaja. Jakarta: Pusat Data dan Informasi Kementrian Kesehatan RI.
Kistanti A. 2008. Buku Pintar Wanita Kesehatan dan Kecantikan. Jakarta: Araska Printika.

Kusmiran, Eni. 2011. Kesehatan Reproduksi Remaja Dan Wanita. Jakarta: Salemba Medica.

Lembaga Penelitian dan Pengabdian Kepada Masyarakat (LPPM). 2016. Panduan Tugas Akhir Akademi Kebidanan Sari Mulia Dan Sekolah Tinggi Ilmu Kesehatan Sari Mulia Banjarmasin. Banjarmasin. STIKES Sari Mulia.

Lestari, Tri. 2013. Buku Ajar Kesehatan Reproduksi. Jakarta: EGC

Miraningsih, Wahyu. 2013. Hubungan Antara Interaksi Sosial Dan Konsep Diri Dengan Perilaku Reproduksi Sehat Pada Siswa Kelas XI Di MAN Purworejo [Skripsi]. Semarang: Universitas Negeri Semarang.

Notoatmodjo. 2005. Promosi Kesehatan Teori Dan Aplikasi. Jakarta :Rineka Cipta.

2007. Promosi Kesehatan Dan Ilmu Perilaku. Jakarta :Rineka Cipta

2010a. Ilmu Perilaku kesehatan. Jakarta: Rieka Cipta

.2010b. Metode

Penelitian

Kesehatan. Jakarta: Rieka Cipta -2012. Promosi Kesehatan Dan Perilaku Kesehatan. Jakarta :Rineka Cipta.

Nursalam. 2010. Konsep Dan Penerapan Metode Penelitian Ilmu Keperawatan. Jakarta: Salemba Medica.

Pinem, Sahora. 2012. Kesehatan Reproduksi dan Keluarga Berencana. Jakarta: Trans Info Media.

Pratiwi, R A. 2009. Hubungan Konsep Diri Dan Konformitas Dengan Perilaku 
Merokok Pada Remaja. [Skripsi]. Universitas Sebelas Maret.

Pribakti. 2013. Tips Dan Trik Merawat Organ Intim. Jakarta: Sgung Seto.

Rahmat H. 2003. Psikologi Komunikasi. Bandung: Rosdakarya.

Rahyani, Ni Komang. 2012. Kesehatan Reproduksi, Buku Ajar Kebidanan. Jakarta: EGC

Siregar, Syofian. 2014. Statistik Parametrik Untuk Penelitian Kuantitatof Dilengkapi Dengan Perhitungan Manual Dan Aplikasi SPPS Versi 17. Jakarta: Bumi Aksara

Setyorini, A. 2014. Kesehatan Reproduksi Dan Pelayanan Keluarga Berencana. Bogor: In Media.

Sobur. 2009. Psikologi Umum Dalam Lintas Sejarah. Bandung: Pustaka Setia.

Sugiyono. 2007. Statistika Untuk Penelitian. Bandung: CV Alfabeta.

Sugono, D. 2008. Kamus Besar Bahasa Indonesia. Jakarta: Pusat Bahasa.

Taufiqurrahman. 2009. Pengantar Metode Penelitian untuk Ilmu Kesehatan. Surakarta; UNS Press.

Prawirohardjo Sarwono . 2008 .Ilmu Kandungan. Jakarta: Yayasan Bina Pustaka Sarwono Prawirohardjo.

$\begin{array}{lcc}\text { kebidanan. Jakarta: } & \text { Yayasan } & \text { Blmu } \\ \text { Pustaka Sarwono Prawirohardjo. } & \end{array}$

Wawan, A . 2011. Teori Dan Pengukuran, Pengetahuan, Sikap Dan Perilaku Manusia. Jogyakarta: Muha Medika

Widyastuti, Yani. 2009. Kesehatan Reproduksi. Yogyakarta: Fitramaya.
Widjajanto, Stanislaus. Infeksi Organ Reproduksi. Infeksi Organ Reproduksi [Internet]. [ dinduh 2017. Maret 03]. Tersedia pada: www.angsamerah.com

Wiknjosastro H. 2008. Ilmu Kebidanan. Jakarta : Bina Pustaka Sarwono Prawirohardjo.

Yanti. 2011. Buku Ajar Kesehatan Reproduksi Untuk Mahasiswa Kebidanan. Yogyakarta: Pustaka Rihama.

Yunita, Rika. 2011. Hubungan Tingkat Pengetahuan Dan Peran Orang Tua Terhadap Perilaku Hgyine Organ Reproduksi Wanita Pada Sisa SMP Nasional Bantul DIY .[Skripsi]. Yogyakarta: Sekolah Tinngi Ilmu Kesehatan Aisyiah Yogyakarta. 